\title{
Słuchanie słowa i łamanie chleba jako memoria resurrectionis (Łk 24, 13-35)
}

Idąc za niektórymi komentatorami, wydarzenia opisane w Łk 24, 13-35 można nazwać streszczeniem wszystkiego, co Łukasz przekazał w 23 rozdziałach swojej Ewangelii ${ }^{1}$. Bowiem całe dzieło Łukaszowe powstało po to, aby przekonać wszystkich miłujących Boga o prawdziwości nauki Jezusa Chrystusa (zob. Łk 1,1-4). Taki właśnie charakter ma opis wydarzeń, które miały miejsce w drodze do Emaus i w samej miejscowości. Jeśli jednak przyjmiemy, iż to opowiadanie jest tylko Łukaszowym summarium, to zasadnym staje się pytanie o prawdziwość i historyczność tego opisu. Chcąc zatem poznać rolę i znaczenie Łk 24, 13-35, należy najpierw spojrzeć na różne ujęcia historii tekstu, a także przyjrzeć się znaczeniu samej miejscowości w tym opowiadaniu czy też bohaterom w nim występującym. Potem zastanowimy się, dlaczego Łukasz z tak wielką mocą podkreśla słuchanie słowa i łamanie chleba.

\section{Czy historia o drodze do Emaus jest jedynie dziełem Łukasza?}

Opowiadanie o wydarzeniach, które miały miejsce w drodze do Emaus, według niektórych komentatorów jest legendą czy też opowiadaniem utworzonym przez autora trzeciej ewangelii ${ }^{2}$. Na uwagę zasługuje opinia R. Bultmanna, opiera się on na opinii H. Gunkela i stwierdza, iż Łk 24, 13-35 jest typową legendą opartą na podobnych historiach, które moż-

${ }^{1}$ Zob. I. Gargano, Lectio divina do opisów zmartwychwstania, Sandomierz 2003, s. 117.

${ }^{2}$ Zob. np. H. D., Betz, The Origin and Nature of Christian Faith according to the Emmaus Legend (Luke 24, 13-35), „Interpretation” 23 (1969), s. 32-46; C. F. Evans, Resurrection and the New Testament, London 1970, s. 92-95 (Studies in Biblical Theology, 12). 
na znaleźć na kartach Starego Testamentu czy nawet w tradycji innych starożytnych religii ${ }^{3}$. Rzeczywiście bowiem w opowiadaniu Łukasza można odnaleźć opisy przypominające Rdz 18, gdzie „mężczyzna” będący Boską postacią spożywa posiłek u Abrahama nieświadomego wydarzeń, które są jego udziałem. Podobna sytuacja znajduje się w Rdz 19, gdzie przedstawione jest spotkanie Lota z dwoma posłańcami - aniołami, którzy przybyli do Sodomy. Lot zaprasza ich do swojego domu, by tam odpoczęli i posilili się. Trudno stwierdzić jednoznacznie, czy Łukasz czerpał ze starotestamentalnych tekstów, opisując wydarzenia mające miejsce po zmartwychwstaniu ${ }^{4}$.

W opinii grupy komentatorów kwestionujących historyczność przekazu drogi do Emaus opis Łk 24, 13-35 nieprzypadkowo powstał i był przekazywany we wspólnocie bliskiej Łukaszowi. W ich opinii fragment ten mógł w znacznej mierze usprawiedliwiać i podkreślać znaczenie innych pasterzy - nie tylko samych apostołów - oraz wagę czynności liturgicznych. Potwierdzeniem dla takich poglądów są według tych autorów liczne pytania, które mogą nasuwać się przy lekturze Łk 24. Przede wszystkim zastanawiający może być fakt niezwykle szczegółowego opisu wydarzenia Łk 24, 13-35, podczas gdy inne relacje ostatniego rozdziału, szczególnie ta opisująca Piotra u grobu (Łk 24,12), ale również i te następujące po relacji z drogi do Emaus, mówiące o przyjściu Jezusa do wspólnoty jedenastu (Łk 24, 36-49) są dość krótkie i zdawkowe. Zastanawiające w opinii tych badaczy może być to, że Łukasz uznał za bardzo ważne objawienie się Jezusa osobom niebędącym apostołami i poświęcił temu wydarzeniu znacznie więcej miejsca niż chociażby spotkaniu Zmartwychwstałego z samym Piotrem ${ }^{5}$. Są to przesłanki mogące potwierdzać opinię, że opis wydarzeń mających miejsce w drodze do Emaus i tych, które potem nastąpiły, jest materiałem zasadniczo

${ }^{3}$ Zob. J. A. Fitzmyer, The Gospel According to Luke X-XXIV, New York-London-TorontoSydney-Auckland 1983, s. 1556 (The Anchor Bible, 28a); J. M. Creed, The Gospel According to St. Luke, London 1950, s. 290.

${ }^{4}$ T. L. Brodie wskazuje, że Łk 24, 13-35 może być imitacją i nawiązaniem do Sdz 19, 5b-21, jednak nie jest to wpływ idei, ale raczej konstrukcji - budowy literackiej, podobnie jak to ma miejsce w innych fragmentach dzieła Łukaszowego - zob. T. L. Brodie, The Birthing of the New Testament, Sheffield 2004, s. 503-510 (New Testament Monographs, 1).

${ }^{5}$ Zob. J. Kremer, Die Osterevangelien - Geschichten um Geschichte, Stuttgart 1977, s. 131-135 (Katholisches Bibelwerk). 
przygotowanym i stworzonym przez Łukasza dla określonych potrzeb ${ }^{6}$, choć z drugiej strony zakorzenionym we wcześniejszej tradycji potwierdzonej u Mk 16, 12-137.

Dla M. D. Goudlera Łukaszowe opowiadanie ma swoje korzenie w materiale Markowym i zostało wykorzystane przez autora trzeciej ewangelii do osiągnięcia pewnych teologicznych celów. Badacz stwierdza, że Łukasz zamierzał jakby przesunąć na drugi plan rolę i znaczenie Piotra w pierwotnej wspólnocie. Potwierdzeniem tego ma być relacja Marka, według której anioł mówi do niewiast, aby te poszły i powiedziały uczniom i Piotrowi, aby wyruszyli do Galilei, gdyż tam ujrzą mistrza (Mk 16, 6-7). Opis Marka wydaje się bowiem wskazywać, że uczniowie - w tym także i Piotr - spotkają Jezusa nie tyle w samej Galilei (pierwsze objawienia nastąpiły w Wielkanoc w pobliżu Jerozolimy), ale w czasie, gdy do niej zdążają. Potwierdzeniem wpływu tekstu Markowego na powstanie Łk 24, 13-35 ma być obecność w tekście historii związanej z Emaus pewnych

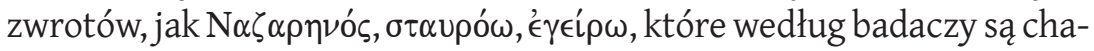
rakterystyczne dla Marka i świadczą o korzystaniu przez Łukasza zjego tekstu. I tak pierwsze z wymienionych określeń występuje w tekstach Łukaszowych zasadniczo w zmienionej i bardziej poprawnej formie

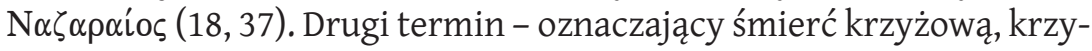
żowanie ${ }^{8}-\mathrm{w}$ tekście Markowym występuje ośmiokrotnie, u Mateusza dziesięć razy. Natomiast Łukasz, mówiąc o ukrzyżowaniu, zasadniczo

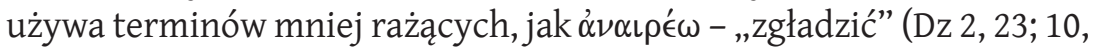

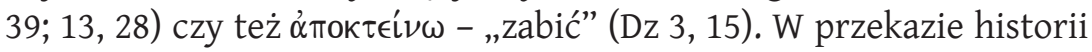
związanej z Emaus posługuje się jednak określeniem pochodzącym z materiału Markowego. Trzeci zwrot obecny zarówno w tekście św. Marka, jak i w Łukaszowym opowiadaniu o Emaus to є $\gamma \epsilon i ́ p \omega$ („,podnieść, powstać") użyte przez Łukasza w stronie biernej, choć zasadniczo autor trzeciej Ewangelii stosuje stronę czynnąa9.

${ }^{6}$ Zob. M. D. Goudler, Luke- a New Paradigm, t. 2: Commentary: Luke 9, 51-24, 53, Sheffield 1989, s. 779 (Journal for the Study of the New Testament Supplement Series, V.20).

${ }^{7}$ Zob. J. A. Fitzmyer, The Gospel According to Luke, dz. cyt., s. 1554.

${ }^{8}$ Zob. R. Popowski, Wielki słownik grecko-polski Nowego Testamentu. Wydanie z petna lokalizacja greckich haset, kluczem polsko-greckim oraz indeksem form czasownikowych, Warszawa $1997^{3}$, s. 563 (Prymasowska Seria Biblijna, 3).

${ }_{9}^{9}$ Zob. M. D. Goudler, Luke - a New Paradigm, dz. cyt., s. 780. 
Warto od razu zwrócić uwagę, iż dla innych komentatorów zwroty te są potwierdzeniem zakorzenienia w prawdziwym przekazie. W ten sposób J. Nolland odnosi się do Kleofasowego określenia Jezusa z Nazaretu, zaznaczając, iż cały wers 19 nosi wyraźne cechy pióra Łukaszowego, a równocześnie jest wyraźnie zakorzeniony w tradycji palestyńskiej. Podobnie rzecz ma się z pozostałymi wymienionymi wcześniej określeniami ${ }^{10}$.

Idąc za myślą M. D. Goudlera, niektórzy komentatorzy stwierdzają, iż dwaj uczniowie zdążający do Emaus: Kleofas i drugi, którego imienia nie znamy, nawiązują do Markowego przekazu: „uczniowie i Piotr” (Mk 16,7). Ponadto Markowa informacja ,idzie przed wami do Galilei” (Mk 16, 7) stała się dla Łukasza bazą dla stwierdzenia: „dwaj z nich byli w drodze do wsi zwanej Emaus, oddalonej sześćdziesiąt stadiów od Jerozolimy" (Łk 24, 13). Wspomniana zaś przez Łukasza miejscowość Emaus leżała na północ od Jerozolimy, która w czasach Jezusa była pierwszym postojem dla podróżujących ku Galilei ${ }^{11}$.

Oprócz materiału Mk 16, 6-7 Łukasz, przygotowując opowiadanie o Emaus, jak również relację przedstawiającą przyjście Jezusa do Wieczernika (Łk 24, 36nn), miał także wykorzystać opuszczony wcześniej duży fragment tekstu Mk 6, 45-8, 26 mówiący o misji Jezusa poza Galileą. Stąd też w opinii niektórych komentatorów historia o wydarzeniach w drodze do Emaus ukazująca niezrozumienie przez uczniów sytuacji, w jakiej się znaleźli, i ich brak wiary nie jest relacją prawdziwych wydarzeń, ale teologicznym zamysłem Łukasza - wyraźnie nawiązuje do przedstawionej w Ewangelii Marka rozmowy Jezusa z uczniami w łodzi (Mk 8, 14-21), jak również do następującego potem wyznania Piotra (Mk 8, 27-33). Całości tych adaptacyjno-redakcyjnych prac autora trzeciej ewangelii przyświecał wyraźnie liturgiczny cel. Historia Emaus miała ukierunkowywać i zachęcać do uczestniczenia w Eucharystii. „Pojawianie się Jezusa podczas łamania chleba i jego natychmiastowe znikanie są nieodłącznymi elementami cotygodniowej

${ }^{10}$ Zob. J. Nolland, Luke (18, 35-24, 53), Dallas 1993, s. 1202 (Word Biblical Commentary, $35 c)$.

${ }^{11}$ Zob. tamże, s. 782. 
Eucharystii" ${ }^{12}$.Jednak większość badaczy nie zgadza się z takim ujęciem tematu łamania chleba. Nie wydaje się, by w opisie ewangelisty Jezus udzielał uczniom komunii. Wydaje się jedynie, że Łukasz próbuje zaznaczyć to, co robili współcześni mu chrześcijanie - przywoływali żywego Pana podczas celebracji eucharystycznych w sposób co najmniej analogiczny do tego z historii uczniów w Emaus ${ }^{13}$.

Równie symboliczna i ważna według autorów przyjmujących w różnej mierze stanowisko M. D. Goudlera jest sama osoba Kleofasa. Według J. Fitzmyera imię Kleofas jest aramejską skróconą wersją greckiego imienia Kleopatrus ${ }^{14}$. Być może Kleofas, bohater Łukaszowego opowiadania to osoba, którą wspomina Ewangelia według św. Jana (J 19, 25). O Kleofasie wspomina Euzebiusz z Cezarei, przekazując wiadomości pochodzące z pamiętników żyjącego tuż po czasach apostołów Hegezypa. Według tego przekazu ,po tym Jakub Sprawiedliwy cierpiał śmierć męczeńską, tak jak i Pan [...] syn wuja jego, Symeon syn Kleofasa został wybrany na biskupa; wszyscy wybrali go, był bowiem kuzynem Pana"15. W opinii niektórych badaczy Kleofas zJ 19, 25, Kleofas z przekazu Hegezypa, którego syn około 62 roku został biskupem Jerozolimy i był nim przez dłuży czas ${ }^{16}$, oraz Kleofas podążający z drugim wędrowcem, którego imienia nie znamy, to jedna i ta sama osoba. Łukasz zaś celowo w swoim przekazie umieszcza wzmiankę o Kleofasie, chcąc podkreślić rolę innych uczniów Chrystusa - niekoniecznie jedynie Piotra. Piotr w przekazie Łukasza jest oczywiście postacią ważną, jednak można odnieść wrażenie, iż towarzysz i lekarz św. Pawła celowo stara się usuwać pierwszego spośród Apostołów nieco w cień. Taka ambiwalencja względem Piotra widoczna szczególnie w Dziejach Apostolskich według pewnych komentatorów mogła mieć wpływ na uformowanie Łk 24.

Rzecz jasna Łukasz uznawał status i rolę Piotra. Miał także wiedzę, że to Piotr był bez wątpienia pierwszym ze świadków zmartwych-

${ }^{12}$ "Christ's being known in the breaking of bread, and his immediate vanishing, are a part of the weekly experience of every Christian at the Eucharist" (M. D. Goudler, Luke - a New Paradigm, dz. cyt., s. 783).

${ }^{13}$ Zob. J. Nolland, Luke, dz. cyt., s. 1208.

${ }^{14}$ Zob. J. A. Fitzmyer, The Gospel According to Luke, dz. cyt., s. 1563.

${ }^{15}$ Euzebiusz z Cezarei, Historia Kościelna, Kraków 1993, IV, 22.

${ }^{16}$ Zob. tamże, III, 32. 
wstałego Jezusa, stąd też wspomina o tym (Łk 24, 34). Czyni to jednak, jak się wydaje, dość zdawkowo. Można odnieść wrażenie, że o wiele większą wagę przywiązuje on do tych uczniów, którym Jezus objawił się w drodze do Emaus. Jednym z nich był właśnie Kleofas ${ }^{17}$. Dlatego M. D. Goudler stwierdza, że „Łukasz wykorzystał Kościół jerozolimski, jego starszyznę i Jakuba, aby zepchnąć Piotra w cień, choć historycznie Jakub stanowił znacznie większe zagrożenie dla Pawła niż dla Piotra"18. Starał się także podkreślić rolę i znaczenie innych uczniów Mistrza z Nazaretu, którzy nie byli apostołami. W takie ujęcie wpisywałaby się również opinia, w myśl której Łukasz poprzez perykopę o Emaus przekazał „historię Wielkanocną tych, którzy prowadzili wspólnotę w Jerozolimie i stamtąd kierowali całym Kościołem"19, czy też historię wielkanocną rodziny Jezusa ${ }^{20}$.

W ujęciu komentatorów zgadzających się z myślą M. D. Goudlera zasadniczo nie ma możliwości wskazania w historii o Emaus materiału, który nawiązywałby do prawdziwej tradycji. Wydaje się, że badacze ci, choć czasami odwołują się do starej palestyńskiej tradycji, zasadniczo wskazują jedynie na Łukasza jako autora tej relacji. Rzecz jasna ewangelista zarówno pod względem językowym, jak i stylistycznym ukształtował opowiadanie o Emaus ${ }^{21}$. Jednak nie oznacza to jeszcze, że historia ta jest własnym dziełem Łukasza. Mając na uwadze zamysł autora trzeciej ewangelii wyrażony w prologu, należy raczej przyjąć, iż wcielił on w swoje dzieło pierwotnie samodzielnie istniejącą historię pojawienia się Jezusa, umieszczając to wydarzenie - być może mając także na względzie przesłanie Marka (Mk 16, 12-14) - między wydarzeniami Łk 24, 11-12 a Łk 24, 36-49. Wydaje się bowiem, że po opisie

${ }^{17}$ Stąd też według Orygenesa towarzyszem Kleofasa mógł być jego syn Symeon - zob. Contra Celsum, II, 62. 68.

${ }^{18}$ M. D. Goudler, Luke - a New Paradigm, dz. cyt., s. 785.

${ }^{19}$ A. Schlatter, Das Evangelium des Lukas. Aus seinen Quellen erklärt, Stuttgart 1931, s. 454; zob. J. Nolland, Luke, dz. cyt., s. 1202.

${ }^{20}$ Zob. W. Grundmann, Das Evangelium nach Lukas, Berlin $1964^{3}$, s. 443 (Theologischer Handkommentar zum Neuen Testament, 3).

${ }^{21}$ Zob. V. Taylor, Q. E. Evans, J. Court, The Passion Narrative of St. Luke: A Critical and Historical Investigation, Cambridge 2004², s. 109-112 (Society for New Testament Studies Monograph Series, 19); J. Wanke, Die Emmauserzählung. Eine redaktionsgeschichtliche Untersuchung zu Lk24, 13ß35, Leipzig 1974, s. 109-114 (Erfurter Theologische Studien, 31). 
Łk 24, 12 mógłby następować fragment Łk 24, 36-43. Natomiast historia dotycząca Emaus płynnie przechodzi z Łk 24, 12 do opisu spotkania uczniów z nierozpoznanym Mistrzem, potem następuje Łk 24, 33-35 i powrót do Jerozolimy ${ }^{22}$.

Warto zwrócić uwagę na to, iż większość komentatorów podkreśla historyczność wydarzenia wspólnej drogi i łamania chleba, rzecz jasna różniąc się co do określenia redakcyjnego wkładu i wpływu Łukasza na kolejne elementy opowiadania. Według niektórych opisana przez Łukasz historia mogłaby wydarzyć się w każdym czasie i na każdym miejscu. Uważają oni, iż niekoniecznie musi być ona łączona z historią zmartwychwstania Jezusa, ale bez wątpienia nawiązuje do uczty miłości i łamania chleba, podczas którego odczuwa się bezpośrednio obecność Pana, i jako taka jest prawdziwym opisem rzeczywistego wydarzenia ${ }^{23}$.

W opinii P. Schuberta pierwotna historia relacjonowała jedynie to, że zmartwychwstały Jezus spotkał dwóch spośród swoich uczniów, którzy Go nie rozpoznali. Dopiero podczas posiłku poznali swojego Pana, który jednak ponownie znik ${ }^{24}$. Podobnie U. Wilckens stwierdza, iż najstarszą warstwą przekazu o wydarzeniach w Emaus jest opis samego posiłku, podczas którego zostaje rozpoznany Jezus Chrystus, do którego to opisu Łukasz dołącza wprowadzenie i zakończenie $e^{25}$. Inni komentatorzy w rozmowie podczas drogi do Emaus i w wyjaśnianiu Pisma przez Zmartwychwstałego widzą pierwszą i najważniejszą intencję przepowiadania: „Metoda dowodu z proroctwa, która tutaj oczywiście nie jest prezentowana, ale jedynie reasumowana, odpowiada dokładnie temu, czym pierwotna wspólnota, zgodnie z relacją Dziejów, rozwiązywała zagadkę cierpienia i śmierci Mesjasza"26.

${ }^{22}$ Zob. J. Ernst, Das Evangelium nach Lukas, Regensburg 1977, s. 655 (Regensburger Neues Testament, 3).

${ }^{23}$ Zob. E. Meyer, Ursprung und Anfänge des Christentums, Stuttgart-Berlin 1921, s. 24.

${ }^{24}$ Zob. P. Schubert, The structure and significance of Luke 24, [w:] Neutestamentliche Studien für Rudolf Bultmann zu seinen siebzigsten Geburtstag, red. W. Elster, Berlin $1957^{2}$, s. 165-187 (Beihefte zur Zeitschrift für die neutestamentliche Wissenschaft und die Kunde der älteren Kirche, 21).

${ }^{25}$ Zob. U. Wilckens, Auferstehung. Das biblische Auferstehungszeugnis historisch untersucht und erklärt, Stuttgart-Berlin 1970, s. 78.

${ }^{26}$ H. Grass, Ostergeschehen und Osterberichte, Göttingen 1970, s. 36. 
Podsumowując, można stwierdzić, iż w sprawie historyczności opowiadania o Emaus istnieją cztery zasadnicze stanowiska. Według jednych Łukasz odtworzył historię, jaką otrzymał, wprowadzając jedynie niewielkie zmiany w treści, ingerując jednak w formę językową. Nie wydaje się bowiem, by większość konstrukcji słownych mogła pochodzić z czasów wcześniejszych. Kolejni badacze twierdzą, że Łukasz otrzymał z tradycji wersję, która skupiała się wokół interpretacji Starego Testamentu przez zmartwychwstałego Chrystusa. Do tego przekazu Łukasz dodał motyw rozpoznania Jezusa po łamaniu chleba. Inni, nawiązując do tej myśli, konstatują, iż to właśnie interpretacja Pisma jest dodatkiem Łukasza do historii łamania chleba. Są także i opinie, które jako dość osobliwe i rzadkie w ogólnym zarysie zostały przywołane na początku niniejszego opracowania, według których Łukasz posiadał jedynie urywki $\mathrm{z}$ tradycji, a historia Emaus jest w zasadniczej mierze jego własnym dziełem teologicznym ${ }^{27}$.

\section{Dlaczego do Emaus?}

Ze sprawą historyczności całego opowiadania łączy się kwestia identyfikacji miejscowości, o której wspomina Łukasz. Zadanie wskazania dziś miejscowości Emaus wydaje się być bez mała niewykonalne ${ }^{28}$. Sam bowiem przekaz trzeciej Ewangelii nie jest w tym względzie całkowicie jasny. Przede wszystkim warto zwrócić uwagę na to, iż Łukasz nic nie mówi o celu podróży. Wędrowcy zatrzymali się w Emaus prawdopodobnie dlatego, że nastawał już zmierzch, co skłoniło ich do schronienia się w gospodzie ${ }^{29}$. Większość świadków tekstu ${ }^{30}$ przekazuje, iż miejscowość Emaus, do której zdążali podróżni, znajdowała się w odległości 60 stadiów $(11 \mathrm{~km})$ od Jerozolimy. Inna ważna grupa kodeksów ${ }^{31}$ przekazuje, iż miejscowość ta znajdowała się w odległości 160 stadiów. Są jednak

${ }^{27}$ Zob. J. Nolland, Luke, dz. cyt., s. 1198.

${ }^{28}$ Szerzej na temat poszczególnych miejsc łączonych ze starożytną miejscowością Emaus zob. J. A. Fitzmyer, The Gospel According to Luke, s. 1561-1562.

${ }^{29}$ Zob. J. Nolland, Luke, dz. cyt., s. 1200-1201.

${ }^{30}$ Spośród najważniejszych należy tu wymienić P $\mathrm{P}^{75}, \mathrm{~A}, \mathrm{~B}, \mathrm{D}, \mathrm{L}, \mathrm{W}, \Delta, \Psi, 070, f^{1}, f^{13}$ $i$ wiele innych.

${ }^{31} \mathrm{~Np} . \mathrm{s}, \mathrm{N}, \Theta$ i inne. 
komentatorzy, którzy uważają, iż wspomniane 60 stadiów Łukasz traktuje jako długość drogi tam i z powrotem z Jerozolimy do Emaus ${ }^{32}$.

Idąc za myślą M. D. Goudlera, należałoby przyjąć, iż wioska Emaus to starożytna osada leżąca w pobliżu Jerozolimy określana mianem Ammaus, opisywana przez Józefa Flawiusza, będąca miejscem osiedlania się weteranów rzymskich ${ }^{33}$. Miejscowość ta znajduje się jednak nie 60 , ale 35 stadiów $(6,5 \mathrm{~km})$ na wschód od Jerozolimy ${ }^{34}$ na trakcie prowadzącym do Joppy. Pielgrzymujący z i do Galilei najczęściej wybierali właśnie tę drogę, gdyż wiodła ona przez teren dość równy, co dawało większą wygodę podróżowania. Nade wszystko podróżujący nią omijali główne centra samarytańskie znajdujące się na wzgórzach. Można więc przyjąć, że właśnie w tej miejscowości zatrzymali się Kleofas, jego towarzysz i nierozpoznany jeszcze Mistrz, podobnie jak czynili to wszyscy inni podróżujący do Galilei. Nie należy przypuszczać według M. D. Goudlera, z czym zgadzają się również i inni komentatorzy, że Emaus było celem podróży, gdyż mowa i sposób zachowania uczniów nosiły cechy właściwe dla mieszkańców Galilei, a zatem zdążali oni do Galilei ${ }^{35}$. Być może rzeczywiście należeli oni do tych, którzy opuszczali zatłoczoną Jerozolimę po zakończonych świętach Paschy ${ }^{36}$.

Według innych biblijne Emaus należy sytuować raczej w miejscu dzisiejszej wioski Amwas, która w czasach rzymskich nosiła nazwę Nikopolis ${ }^{37}$. I tak Orygenes w zagubionym dziś komentarzu do Ewangelii według św. Łukasza stwierdza, iż ewangelicznym Emaus było Nikopolis ${ }^{38}$. Podobne świadectwo można znaleźć u Euzebiusza z Cezarei, który

${ }^{32}$ Zob. J. Nolland, Luke, dz. cyt., s. 1207.

${ }^{33}$ Zob. J. Flawiusz, Wojna żydowska, Warszawa 2001, VII, 217. Jest to współczesna miejscowość Kaloniyeh - zob. E. Schürer, The History of the Jewish People in the Age of Jesus Christ (175 B.C.-A.D. 135), t. 1, Edinburgh 1973, s. 512.

${ }^{34}$ Takie umiejscowienie potwierdza jednak tylko w pewnym sensie jeden świadek tekstu: starołaciński manuskrypt pochodzący z około piątego wieku (it ${ }^{\mathrm{e}}$ ).

${ }^{35}$ Zob. M. D. Goudler, Luke - a New Paradigm, s. 784; inaczej np. J. Ernst, Das Evangelium nach Lukas, dz. cyt., s. 662.

${ }^{36}$ Zob. J. Nolland, Luke, dz. cyt., s. 1201.

${ }^{37}$ Zob. D. Baldi, W ojczyźnie Chrystusa, Kraków-Asyż 1993², s. 209.

${ }^{38}$ Zob. L. H. Vincent, Fouilles de l'École a la basilique d'Amwas, "Revue Biblique" 35 (1926), s. 120. 
zaświadcza, iż Nikopolis nazywano poprzednio Emaus ${ }^{39}$. Świadectwo tego starożytnego historyka jest ważne, gdyż pochodził on z Palestyny i był metropolitą Cezarei Palestyńskiej, do której należało Nikopolis ${ }^{40}$. Podobny przekaz można znaleźć u św. Hieronima, który będąc w 385 roku w Nikopolis, stwierdza, iż miejscowość ta wcześniej nosiła nazwę Emaus - tam też znajdował się dom Kleofasa, który później stał się kościołem. Stąd też w manuskryptach hieronimiańskiej Wulgaty można znaleźć przekaz mówiący o odległości 160 stadiów ${ }^{41}$.

O Amwas-Nikopolis, miejscowości, w pobliżu którejJuda Machabeusz pokonał w 165 roku przed Chrystusem wojsko syryjskie Antiocha IV Epifanesa dowodzone przez Nikanora i Gorgiasza (zob. 1 Mch 3, 14; $4,3)$, wspomina także Józef Flawiusz ${ }^{42}$. Miasto to wielokrotnie umacniane zostało w 4 roku przed Chrystusem zniszczone przez Warusa. Później w 70 roku Tytus obdarzył je tytułem Nikopolis (miasto zwycięskie). Chociaż za tym umiejscowieniem przemawia dość starożytna tradycja ${ }^{43}$, to jednak odległość dzieląca Nikopolis od Jerozolimy (około $32 \mathrm{~km}$ ) wydaje się być zbyt duża. Pamiętać bowiem należy, że podróż z Jerozolimy do Emaus uczniowie rozpoczęli w godzinach przedpołudniowych - były kobiety u grobu, potem poszli i inni, po czym dopiero Kleofas wraz z drugim uczniem wyruszyli z Jerozolimy (Łk 24, 22-24). Powstaje zatem pytanie: czy mogli przebyć tak dużą odległość w ciągu niecałego dnia? Z drugiej jednak strony wydaje się, iż właśnie ta lekcja, mówiąca o odległości 160 stadiów, a zatem lekcja trudniejsza, jest bardziej prawdopodobna.

Wspomnieć wreszcie należy o dzisiejszym sanktuarium eucharystycznym znajdującym się w miejscowości al-Qubeibeh ${ }^{44}$. Z tą właśnie

${ }^{39}$ Zob. Euzebiusz z Cezarei, Onomasticon, 90; tenże, Chronicorum Liber II, PG 19, 569.

${ }^{40}$ Zob. J. Misiurek, Emaus (Lk 24, 13-36), „Ruch Biblijny i Liturgiczny” 31 (1978) nr 5, s. 241-242.

${ }^{41}$ Według komentatorów w wielu tekstach Wulgaty zmieniano później tę odległość na podstawie wersji tekstów greckich - zob. F. M. Abel, La distance de Jérusalem a Emmaus, „Revue Biblique” 34 (1925), s. 355.

${ }^{42}$ Zob. J. Flawiusz, Wojna Żydowska, dz. cyt., II, 63.

${ }^{43}$ Wspomnieć należy m.in. ruiny bazyliki pochodzącej z III wieku, jak również późniejsze budowle, które zostały odkryte podczas wykopalisk archeologicznych w latach 1924-1925 - zob. D. Baldi, W ojczyźnie Chrystusa, dz. cyt., s. 210.

${ }^{44}$ Zob. J. Wanke, Die Emmauserzählung, dz. cyt., s. 37-42. 
wioską, dziś zamieszkaną zasadniczo przez muzułmanów, najbardziej wydaje się korespondować Łukaszowy opis, choć poza informacją o odległości, właściwie nic więcej nie wskazuje na to dzisiejsze franciszkańskie sanktuarium ${ }^{45}$. Odległość bowiem z tej miejscowości do Jerozolimy wynosi właśnie 60 stadiów. Jednakże przekazy o usytuowaniu Emaus w dzisiejszym al-Qubeibeh pochodzą dopiero z średniowiecza. Według niektórych powodem opuszczenia i zapomnienia tej miejscowości mogły być zamieszki wojenne (powstanie żydowskie w 70 bądź $135 \mathrm{roku}$ ), stąd też dopiero późniejsza wzmianka o tej miejscowości i jej identyfikacja z Łukaszowym Emaus. W tej identyfikacji znaczny udział mieli franciszkanie przybyli w 1335 roku do Ziemi Świętej, którzy prowadzili pielgrzymów właśnie do tego miejsca, nawiedzając najpierw salę dawnego zamku, później zaś odkryty „dom Kleofasa”"46.

Wobec niemożności odnalezienia biblijnego Emaus niektórzy uważają, iż Łukasz celowo nie określił szczegółowego położenia miejsca objawienia, gdyż geografia biblijna nie była dla niego najważniejsza. Istotą dla autora trzeciej ewangelii było przepowiadanie ${ }^{47}$.

\section{Przybliżył się i szedł z nimi}

Znamiennym jest, iż czytelnik trzeciej ewangelii może odnieść wrażenie, że wszystkie wydarzenia zapisane w Łk 24, mające miejsce po zmartwychwstaniu Chrystusa dzieją się jednego dnia. Znacząca część Łukaszowego przekazu ma miejsce w drodze, co wydaje się być wyraźnym nawiązaniem do budowy całej trzeciej Ewangelii, w której Jezus jest przedstawiony jako wędrowiec zdążający nieustannie do Jerozolimy. Prawdziwy uczeń Mistrza z Nazaretu to ten, który umie wszystko zostawiać i kroczyć za swoim nauczycielem (zob. Łk 9, 23nn. 57nn). Jednak w tej wędrówce uczniowie nigdy nie są sami. Jezus jest towarzyszem drogi chrześcijan. Kiedy dwóch lub trzech jest w imię Jego w drodze, to On zawsze jest pośród nich, choć bardzo często po-

\footnotetext{
${ }^{45}$ Zob. J. Nolland, Luke, dz. cyt., s. 1201.

${ }^{46}$ Szerzej na ten temat zob. B. Bagatti, I monumenti di Emmaus al-Qubeibeh e dei dintorni, Jerozolima 1947.

${ }^{47}$ Zob. J. Wanke, Die Emmauserzählung, dz. cyt., s. 26.
} 
zostaje nierozpoznany ${ }^{48}$. Prawdę o tym, iż każdy uczeń Chrystusa jest

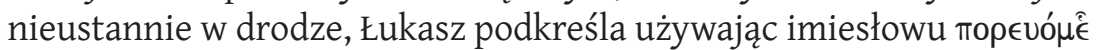
vol (,podążający”) ${ }^{49}$.

Wydaje się, iż ci dwaj uczniowie nie należeli do ścisłego kręgu jedenastu apostołów wspomnianych przez ewangelistę w Łk 24, 11. Raczej przynależeli do wspólnoty sympatyków i innych uczniów Jezusa ${ }^{50}$. Wspominając o Kleofasie, Łukasz zapewne celowo nie podaje imienia drugiego ucznia, aby każdy czytelnik mógł dostrzec w nim siebie samego. Obaj zdruzgotani wydarzeniami, które miały miejsce w Jerozolimie, pełni smutku i żalu prowadzą ze sobą rozmowy, które Łukasz określa mianem ó $\mu \iota \lambda \hat{\epsilon} \omega$ - czyli przemawiania czy też głoszenia sobie mów ${ }^{51}$. Prowadzenie takich rozmów podczas podróży było w tradycji żydowskiej zwyczajem znanym i pochwalanym ${ }^{52}$. Jednak w tym przypadku dyskusja nie daje żadnych rezultatów. Stąd też konieczne jest wkroczenie Jezusa.

Pojawienie się nierozpoznanego przez podróżnych Mistrza z Nazaretu ${ }^{53}$ Łukasz podkreśla użyciem formuły nietłumaczonej na język polski

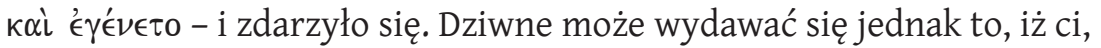
którzy jeszcze nie tak dawno słuchali nauk Jezusa i zapewne wielokrotnie widzieli Mistrza z Nazaretu, nie potrafili Go rozpoznać, zdążając do Emaus. Nie wiemy, dlaczego tak się stało. Być może sprawiło to ich rozczarowanie, zawiedzione nadzieje, a co za tym idzie, wpływ Złego ${ }^{54}$.

Odpowiadając na pytanie nierozpoznanego Chrystusa o temat prowadzonej w drodze dyskusji, Kleofas przedstawia opowiadanie pełne wielkiego smutku. Dziwiąc się, iż Nieznajomy nic nie wie o wydarzeniach, które miały miejsce w Jerozolimie, przygnębiony Kleofas opowiada całą

${ }^{48}$ Zob. J. Ernst, Das Evangelium nach Lukas, dz. cyt., s. 658.

${ }^{49}$ A zatem dwaj uczniowie podążali, byli w podróży, byli w drodze - zob. R. Popowski, Wielki słownik grecko-polski, dz. cyt., s. 515.

${ }^{50}$ Zob. K. H. Rengstorf, Das Evangelium nach Lukas, Göttingen $1958^{4}$, s. 281 (Das Neue Testament Deutsch, 3); J. Nolland, Luke, dz. cyt., s. 1200.

${ }^{51}$ Zob. R. Popowski, Wielki słownik grecko-polski, dz. cyt., s. 426; I. Gargano, Lectio divina do opisów zmartwychwstania, dz. cyt., s. 115.

${ }^{52}$ Zob. P. Billerbeck, H. L. Strack, Kommentar zum Neuen Testament aus Talmud und Midrasch, t. 2, München 1969, s. 273.

${ }^{53}$ Zmartwychwstały posiada pewną cielesność, w której jednak nie rozpoznają Go uczniowie - zob. K. H. Rengstorf, Das Evangelium nach Lukas, dz. cyt., s. 282.

${ }^{54}$ Zob. J. Nolland, Luke, dz. cyt., s. 1207. 
historię wydarzenia Jezusa. Szczególnie znamienne jest Kleofasowe

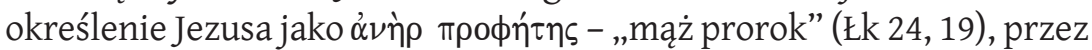
co ewangelista, podobnie jak w Dz 3, 22-23 czy Dz 7, 35. 37, wyraźnie nawiązuje do typologii Mojżesza ${ }^{55}$. Kolejne wypowiadane przez Kleofasa słowa mogą być także uznane za jego wyznanie wiary w mesjańskość Jezusa. Ta wiara została jednak zachwiana czy wręcz zburzona przez mękę i śmierć krzyżową, której sprawcą był cały naród wybrany. Łukasz, zaznaczając, iź winnymi śmierci Jezusa byli ,arcykapłani i nasi przywódcy" $\left(€ k\right.$ 24, 20), podkreśla odpowiedzialność całego Izraela ${ }^{56}$. Opinia mówiąca, iż milczenie na temat Piłata i Rzymian może wskazywać na antysemityzm trzeciej ewangelii, wydaje się być nieuzasadniona ${ }^{57}$.

W przekazie podróżnych śmierć Mistrza z Nazaretu ma charakter ostateczny i nieodwołalny. Stąd też i pokreślenie ucznia, że od tego czasu minęło już trzy dni. Stwierdzenie to, według niektórych, miało służyć podkreśleniu dziwnego faktu, że tajemniczy Nieznajomy, choć wyruszył z Jerozolimy, to jednak nic nie słyszał o wydarzeniach, które tam miały miejsce. Wydaje się jednak, iż informacja o „trzech dniach”, które minęły od śmierci Jezusa, ma inny cel. Podkreślenie to potwierdza, jak można domniemywać, prawdziwość opowiadania. Nie należy bowiem sądzić, iż Łukasz mógł ten szczegół sam utworzyć. Zgodnie bowiem z żydowskimi wyobrażeniami dusza unosi się nad ciałem przez trzy dni po ich rozdzieleniu. Gdy ten okres minie, nie można już liczyć na powrót zmarłego do życia ${ }^{58}$. A zatem Kleofas pragnie podkreślić nieodwołalność śmierci Jezusa.

Szczególnie ważnym elementem przekazu Kleofasa jest informacja, że zarówno niewiasty jak i uczniowie, którzy pobiegli sprawdzić, czy przyniesione wiadomości są prawdziwe, potwierdzają, że Jezusa nie ma w grobie. Co bardziej istotne, powracające kobiety wyraźnie dają świadectwo, że spotkani przez nie aniołowie zaświadczają, iżJezus żyje. Świadectwo niewiast „On żyje” staje w centrum przesłania historii o Emaus. Opiera się ono na świadectwie nie jednego, ale kilku świadków - aniołów (liczba mnoga). Na tle tych wydarzeń i wiadomości niezrozu-

\footnotetext{
${ }^{55}$ Zob. J. Wanke, Die Emmauserzählung, dz. cyt., s. 64.

${ }^{56}$ Zob. tamże, s. 59.

${ }^{57}$ Zob. J. Nolland, Luke, dz. cyt., s. 1202.

${ }^{58}$ Zob. J. Ernst, Das Evangelium nach Lukas, dz. cyt., s. 660.
} 
miałe staje się postępowanie dwóch uczniów zdążających do Emaus. Nikt nie widział na własne oczy Zmartwychwstałego, w przekazie Łukasza Jezus jeszcze nikomu się nie objawił, ale jednak grób był pusty. Mimo to uczniowie uciekają z Jerozolimy, zamiast udać się i na własne oczy przekonać się o tajemnicy pustego grobu. Sytuacja ta jest dla Łukasza sposobnością, aby pokazać, że aby uwierzyć, konieczne jest spotkanie ze Zmartwychwstałym. Bez spotkania z Nim nie można osiągnąć prawdziwej wiary ${ }^{59}$.

Cała rozmowa między uczniami a nierozpoznanym przez nich Jezusem jest w zasadzie dość ironiczna. Uczniowie bowiem mówią o ignorancji Nieznajomego związanej z osobą i dziełem Mistrza z Nazaretu, nie zdając sobie w rzeczywistości sprawy, że rozmawiają z samym Jezusem. Co więcej, tak naprawdę to oni sami nie rozumieją wydarzenia Jezusa ${ }^{60}$.

Całej tej relacji Kleofasa Jezus przysłuchiwał się milcząco. Dopiero gdy uczniowie ujawnili powód swojego smutku, daje im On pouczenie, które rozpoczyna od upomnienia. Jezus podkreśla brak zrozumienia i ociężałość serca obu uczniów, którzy otrzymali wiele znaków i dowodów, a mimo to ich postępowanie i wiara nie zmieniły się. A wystarczyłoby tylko z uwagą i pilnością przeczytać Pisma, w których zawierała się cała historia Jezusa ${ }^{61}$. Chrystus wyjaśnia im więc Pisma, rozpala w ich wnętrzach niezwykły żar, który później pozwoli im uwierzyć bez reszty i stać się prawdziwymi świadkami. Oni sami, rozpoznawszy Jezusa, stwierdzą: „,zy serce nie pałało w nas, kiedy rozmawiał z nami w drodze i Pisma nam wyjaśniał" (Łk 24, 32).

Dla Łukasza dokładna treść, dokładny przekaz słów wypowiedzianych przez nierozpoznanego przez uczniów Mistrza nie są istotnie ważne. Autor trzeciej ewangelii relacjonuje tylko, że Jezus wyjaśniał, co we wszystkich Pismach, począwszy od Mojżesza i proroków, odnosiło się do Niego. A zatem w przekazie Łukaszowym to Jezus jest celem Pisma, jak również jego najważniejszym interpretatorem. Jest tym, który najpełniej odczytuje i otwiera słuchających na prawdy zawarte w tekście natchnionym. „Biblia chce być obserwowana i czytana od końca, ażeby

${ }^{59}$ Zob. tamże, s. 661; J. Nolland, Luke, dz. cyt., s. 1202.

${ }^{60}$ Zob. J. Nolland, Luke, dz. cyt., s. 1208.

${ }^{61}$ Zob. E. Lohse, Die AuferstehungJesu Christi im Zeugnis des Lukasevangeliums, Neukirchen 1961, s. 28 (Biblische Studien, 31). 
ze wszystkich ksiąg zostało usłyszane jedno Słowo Boga o Chrystusie. Od końca sięga się do początku i potem od Mojżesza poprzez proroków dochodzi się znowu do końca. Chrystus jest zatem celem i centrum całego Pisma"62.

\section{Poznali Go}

Zaproszenie uczniów skierowane do jeszcze nierozpoznanego Jezusa, aby pozostał wraz z nimi i zjadł wieczerzę, nawiązuje do tradycji żydowskiej, w której główny posiłek dnia spożywano zwykle późnym popołudniem. W świecie starożytnym gościnność względem obcych była ceniona równie wysoko jak gorliwość religijna ${ }^{63}$.

Dlatego bardzo ważną informacją dla Łukasza jest to, iż zbliżywszy się do miejscowości Emaus, uczniowie przymusili Towarzysza, aby ten pozostał wraz z nimi. Według niektórych wahanie nierozpoznanego Jezusa wpisuje się w konwencje gościnności Bliskiego Wschodu ${ }^{64}$. Namowy uczniów wynikały zapewne z zasad gościnności, z tego, że pora była już późna, ale i z wielkiego pragnienia słuchania i przebywania w towarzystwie wciąż nierozpoznanego Wędrowca. Dla Łukasza jednak jest to sposobność dla podkreślenia prawdy, iż człowiek pragnący spotkać się z Chrystusem musi Go na to spotkanie zaprosić, namówić na przyjście. Można odnieść wrażenie, że również sam Jezus oczekuje, że uczniowie zaproszą Go na wspólne łamanie chleba.

Również i to pewnego rodzaju "natrętne” naleganie jest zgodne z obyczajami ludzi orientu ${ }^{65}$. Łukasz zamieszcza informację o przyjęciu zaproszenia przez Jezusa, aby pokazać przyszłym uczniom, co mają czynić, aby Mistrz zamieszkał pośród nich i dał jasność poznania. Można powiedzieć, że zaproszenie uczniów stało się dla Łukasza sposobnością, by opisać prośbę - modlitwę do Jezusa. Jest to Łukaszowe życzenie i wskazówka dla wszystkich uczestników każdego łamania chleba ${ }^{66}$.

${ }^{62}$ Tamże, s. 29.

${ }^{63}$ Zob. J. Jeremias, Eucharistic words of Jesus, Oxford 1955, 44-45.

${ }^{64}$ Zob. J. Ernst, Das Evangelium nach Lukas, dz. cyt., s. 662.

${ }^{65}$ Zob. J. Schmid, Das Evangelium nach Lukas, Regensburg $1955^{3}$, s. 358 (Regensburger Neues Testament, 3).

${ }^{66}$ Zob. J. Wanke, Beobachtungen zum Eucharistieverständnis des Lukas, Leipzig 1973, s. 44 (Erfurter Theologische Schriften, 8). 
Wydarzenia w gospodzie jednak nie przebiegają tak, jak każe tradycja. To nie zapraszający jest gospodarzem, tylko zaproszony Jezus przejmuje obowiązki gospodarza. Bierze chleb, odmawia modlitwę dziękczynną, łamie i rozdziela go ${ }^{67}$. Było to zachowanie charakterystyczne dla Jezusa z czasów Jego publicznej działalności, stąd też po tym geście można Go było z łatwością poznać ${ }^{68}$. Samo bowiem działanie nie ma w sobie nic nadzwyczajnego. W swoich poszczególnych częściach jest ono ustalone przez żydowskie zwyczaje związane ze wspólnym spożywaniem posiłku. Sam Jezus podczas publicznej działalności bardzo często spożywał posiłki ze swoimi uczniami w ten właśnie sposób (zob. Łk 9, 16). Również wspólnota pierwotnego Kościoła kontynuowała praktykę codziennych wspólnotowych posiłków, które nie były zawsze identyczne z Eucharystią (zob. Dz 2, 42. 46) ${ }^{69}$.

Formuła „łamanie chleba” pojawia się w Nowym Testamencie tylko dwa razy (Łk 24, 35; Dz 2, 42). Wydaje się, iż Łukasz przejął tę formułę z wcześniejszej tradycji ${ }^{70}$. 0 ile większość komentatorów przychyla się do uznania, że w Dz 2, 42 można mówić o eucharystycznej interpretacji formuły „łamanie chleba”, to w Łk 24, 35 nie jest to już takie oczywi$s^{71}$. Wydaje się bowiem, że dopiero później powstało pojęcie „łamanie chleba" jako terminus technicus uczty Pańskiej. W Łukaszowym tekście na płaszczyźnie przebiegu wydarzeń nie ma raczej żadnego eucharystycznego odniesienia. Nie wydaje się, by Jezus jako zmartwychwstały Pan chciał powtórzyć wieczerzę Wielkiego Czwartku. Raczej łamał i rozdzielał chleb jak to było zwyczajem podczas każdego posiłku.

Rzecz jasna, iż nie może jednak zostać przeoczone to, że Łukasz widział i przedstawił to powszednie wydarzenie w świetle wczesnochrześcijańskiej celebracji Eucharystii. Można powiedzieć, że jak w opowiadaniach Dziejów Apostolskich, tak i w opisie Łk 24 liturgia formuje tradycję ${ }^{72}$. Być może również we wzmiance o rozpoczynającej się porze wieczor-

${ }^{67}$ Zob. J. Nolland, Luke, dz. cyt., s. 1206.

${ }^{68}$ Zob. J. Jeremias, Die Abendmahlsworte Jesu, Göttingen $1960^{3}$, s. 114

${ }^{69}$ Zob. P. Łabuda, Znaczenie chleba w Biblii, [w:] Eucharystia - pokuta i pojednanie w katechezie, red. J. Stala, Kielce 2007, s. 15-30.

${ }^{70}$ Zob. J. Wanke, Die Emmauserzählung, s. 46.

${ }^{71} \mathrm{Na}$ ten temat zob. K. Romaniuk, „Eamanie Chleba”, „Ruch Bibilijny Liturgiczny” 40 (1987) nr 1, s. 1-7.

${ }^{72}$ Zob. J. Wanke, Beobachtungen zum Eucharistieverständnis des Lukas, dz. cyt., s. 44. 
nej jest ukryta wskazówka dotycząca pory nabożeństw młodej gminy (por. Dz 2, 42. 45; 4, 35).

Kleofas i drugi nienazwany z imienia uczeń raczej nie wiązali gestów Jezusa z Eucharystią, ponieważ nie należeli oni do grona dwunastu apostołów. Nie byli zatem w wieczerniku i nie wiadomo, czy w ogóle już wiedzieli o wydarzeniach, które miały tam miejsce. Łukaszowe określenie „poznali Go podczas łamania chleba” podkreśla nie czynność, ale czas kiedy poznali Pana ${ }^{73}$. Mówiąc o „łamaniu chleba”, warto pamiętać, iż określenie to oznaczało nie tylko samą czynność dzielenia placków macy i podawanie uczestnikom wieczerzy, ale także i modlitwę, która tę czynność poprzedzała. A zatem nie jest wykluczone, że w modlitwie tej Jezus użył słów, które były dla Niego charakterystyczne i dlatego uczniowie rozpoznali Go właśnie po nich ${ }^{74}$.

U początku tej niezwykłej wieczerzy Łukasz po raz kolejny używa

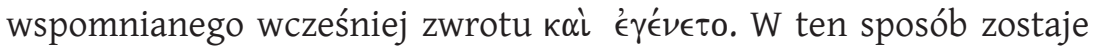
podkreślony początek nowej niejako części w opowiadaniu historii o Emaus. Po czasie zwątpienia, a potem słuchania słowa, nadchodzi czas niezwykłego wydarzenia. Stąd też Łukasz poprzez taki zwrot pragnie czytelnika pobudzić i zmobilizować do jeszcze większej czujności na zbliżające się wydarzenie.

Wydarzenie łamania chleba ma niezwykły przebieg. Gdy Chrystus odmówił błogosławieństwo, wziął chleb, połamał go i podał im, oczy obydwu uczniów zostały całkowicie otwarte. Tak należałoby dokładnie rozumieć użyty tu czasownik $\delta\llcorner\alpha \nu o i ́ \gamma \omega$. Forma indicativus aoristi passivi wydaje się podkreślać Jezusa jako sprawcę wydarzenia pełnego otwarcia oczu. To pełne otwarcie jest dla obu uczniów początkiem nowego, niezwykłego życia. Łukasz podkreśla, że po otwarciu oczu i zniknięciu Chrystusa uczniowie mają w sobie niezwykłą moc - natychmiast wstają i wracają do Jerozolimy. Spotkanie ze Zmartwychwstałym w czasie łamania chleba jest przyczyną przemiany w sercach uczniów. Stąd też

${ }^{73}$ Zob. J. Jeremias, Die Abendmahlsworte Jesu, s. 114; J. Schmid, Das Evangelium nach Lukas, dz. cyt., s. 359.

${ }^{74}$ Zob. J. Jeremias, Die Abendmahlsworte Jesu, dz. cyt., s. 114. Trzeba jednak dla całości rozważań dodać, że są również komentatorzy, którzy w żadnej mierze nie widzą w łamaniu chleba w Łk 24 nawiązania do Eucharystii - zob. J. Ernst, Das Evangelium nach Lukas, dz. cyt., s. 663. 
Łukasz stwierdza, że uczniowie „wstali” ( $\left.\nu^{\prime} \mathbf{\sigma} \tau \eta \mu \iota\right)$. Warto jednak pamiętać, iż czasownik ten posiada znaczenie szersze: podnosić się, wzbudzać się, zmartwychwstawać, budzić się do życia ${ }^{75}$. A zatem uczniowie do tej pory pełni smutku, żalu, a zapewne także i strachu teraz wracają niejako do życia - budzą się ze swoistego letargu.

Wzbudzeni do życia, czują potrzebę dawania świadectwa. Poznane i zrozumiałe objawienie staje się dla nich imperatywem. Pomimo późnej godziny, mimo niebezpieczeństw, jakie ze sobą niesie podróżowanie nocą, wyruszają w powrotna drogę do Jerozolimy, by zanieść Jedenastu i pozostałym radosne orędzie. Krótka wzmianka o „powrocie” ma obok funkcji narracyjnej także wysoką wartość w przepowiadaniu. Gdziekolwiek ludzie zostali łaskawie nawiedzeni przez Boga (zob. Łk 2, 20; 9, 10; 10, $17 ; 17,15 ; 23,48)$, czują wewnętrzną potrzebę i zobowiązanie, by przepowiadać i wyznawać to, czego doświadczyli. Dla Łukaszowej teologii drogi ważne jest to, że teraz dzieje się to w Jerozolimie, stamtąd zaś dobra nowina o zbawieniu zostanie rozpowszechniona na cały świat ( $Ł k$ 24, 47 ; Dz 1, 8). Motyw powrotu ma ponadto funkcję wynikającą z podanej w Łk 24, 13 informacji o oddaleniu się od świętego miasta. „Oddalenie się od miasta, w tym wypadku równoznaczne z oddaleniem od Jezusa i przyszłej gminy, zostaje przez objawienie Zmartwychwstałego nadrobione i odwrócone w ruch w kierunku miasta"76. Powrót do Jerozolimy jest pospieszny. Takie postępowanie uczniów jest podyktowane radością, odbudowaną wiarą i pragnieniem dawania świadectwa. Ważną jednak rolę ma tu także Łukaszowe podkreślenie faktu, iż wszystkie wydarzenia Łk 24 odbywają się niejako w obrębie Wielkiej Nocy ${ }^{77}$. Od chwili zmartwychwstania Jezusa czas jakby przestaje odgrywać ważną rolę. Najważniejsze jest bowiem bycie z Chrystusem.

Wracający do Jerozolimy Kleofas i jego towarzysz zastają uradowanych uczniów, którzy jako pierwsi przekazują im radosną wiadomość. Dopiero później również podróżni, którzy przybyli z Emaus, dzielą się swoim spotkaniem. Według J. Wankego, inaczej niż sugeruje to M. D. Goudler, Łukasz stara się o chronologiczny porządek w ukazywaniu

${ }^{75}$ Zob. R. Popowski, Wielki słownik grecko-polski, dz. cyt., s. 45-46.

${ }^{76}$ G. Lohfink, Die Himmelfahrt Jesu: Untersuchungen zu den Himmelfahrts- und Erhöhungstexten bei Lukas, Münich 1971, s. 264.

${ }^{77}$ Zob. J. Nolland, Luke, s. 1206. 
tajemnicy zmartwychwstania. Stąd też po objawieniu Piotrowi, Jezus daje się poznać uczniom zmierzającym do Emaus, potem zaś Jedenastu i ich towarzyszom ${ }^{78}$. Doświadczenie wielkanocne uczniów zmierzających do Emaus zostaje potwierdzone i wsparte przez Piotrowe przeżycie zmartwychwstania. Zostaje tutaj podana jasna odpowiedź na pytanie o korzenie wiary wielkanocnej: pusty grób i prywatne świadectwo przemawiają dopiero wtedy, gdy są złączone z wyznaniem wiary wielkanocnej wspólnoty ${ }^{79}$.

Słuchanie słowa i łamanie chleba stają się swoistym memoria resurrectionis - czasem spotkania i medytowania tajemnicy Chrystusa. W tym znaczeniu można całe wydarzenie Emaus rozpatrywać i odnosić do każdorazowej Eucharystii. Każde bowiem słuchanie słowa i łamanie chleba jest memoria resurrectionis prowadzącym do prawdziwej wiary. Tarnów

KS. PIOTR ŁABUDA

\section{Słowa kluczowe}

Zmartwychwstanie, Emaus, łamanie chleba, Eucharystia

\section{Summary}

The hearing of God's Word and breaking of the bread as memoria resurrectionis (Luke 24, 13-35)

In Luke's history written down in Luke 24,13-35 the acts of hearing God's Word and breaking of the bread are characteristic of memoria resurrectionis - the time of discovering and meditating on Christ's mystery. Therefore the whole event in Emmaus may be looked into this sense and may be referred to each Eucharist. Every act of hearing God's Word and breaking of the bread is the memoria resurrectionis which leads to the true faith. The critical analysis of both the historical nature of Luke's work and the places, people and events described by the author of the third Gospel allows for such interpretation of this pericope.

\footnotetext{
${ }^{78}$ Zob. J. Wanke, Die Emmauserzählung, dz. cyt., s. 52.

${ }^{79}$ Zob. tamże, s. 53.
} 
Keywords

Resurrection, Emmaus, breaking of the bread, Eucharist 